\title{
One Hundred of the Most Invasive Alien Species in Europe
}

\author{
Montserrat Vilà, Corina Başnou, Stephan Gollasch, Melanie Josefsson, \\ Jan Pergl, and Riccardo Scalera
}

One of the primary tools for raising awareness on biological invasions has been the publication of species accounts of the most prominent alien invaders. Until now such compilations have been available only for particular taxa, biomes and/or regions (Cronk and Fuller 2001; Weber 2003; Weidema 2000). In Europe, species accounts for selected invasive species have been published for a few countries or regions: the Czech Republic (Mlíkovský and Stýblo 2006), France (Pascal et al. 2006), Italy (Andreotti et al. 2001; Scalera 2001), Spain (Capdevila-Argüelles and Zilletti 2006); the Mediterranean Sea (CIESM 2007), and the North European and Baltic region (Gollasch et al. 1999; NOBANIS 2007). These accounts highlight invasive alien species which cause significant harm to biological diversity, socioeconomic values and human health in these regions. The main purpose of these accounts is to provide guidance to environmental managers and raise public awareness of the biological, ecological and socio-economic impacts of the most harmful invaders, together with a description of the main management options to prevent their spread and reduce their impacts. The importance of the role of such tools has been clearly shown by the IUCN's 100 of the World's Worst Invasive Species list (Love et al. 2000) which has been very influential in raising awareness and supporting the development of policy conservation instruments relevant to biological invasions (Shine et al. 2000).

The European Environmental Agency has produced, within the SEBI 2010 project, a list of the worst invasive alien species threatening biological diversity in Europe (EEA 2007). This list contributes to the general indicator of changes in biological diversity caused by invasive alien species. The SEBI 2010 list is primarily a means to communicate the issue of invasive species to policymakers, stakeholders and the general public. The selection of the 168 species on the list was carried out in an open consultative process with an expert group, the scientific community and national environmental authorities. The main criterion used for selection was that the species have a serious impact on biological diversity at the regional level. Serious impact implies that the species has severe effects on ecosystem structure and function, it can replace native species throughout a significant proportion of its range, it can hybridise with native species or threaten biodiversity. In addition, the species can have negative consequences for human activities, health and/or economic interests. 
Following the experience of SEBI 2010, the species accounts realised within the DAISIE project have been prepared with the purpose of delivering a synthesis of the most relevant up-to-date information on the ecology, distribution and impact of 100 of the most invasive species. These accounts are particularly designed for supporting actions dealing with biological invasions in Europe. For this reason, although they cannot be considered to be exhaustive, the DAISIE accounts may play a major role in raising public awareness and supporting the activities of a broad spectrum of professionals including land-use and wildlife managers, environmental policymakers, environmental educators, journalists, students and other stakeholders. On this regard, there are already examples on how DAISIE might offer a major contribution to the development of policy tools to face the threats of alien species. Indeed, it is a remarkable fact that the 100 of the most invasive species have been used as a basis for the realisation of a document for the Council of Europe titled "Towards a black list of invasive alien species entering Europe through trade, and proposed responses” (Genovesi and Scalera 2007), which led to Recommendation No. 125 (2007) of the Standing Committee, adopted on 29 November 2007, on trade in invasive and potentially invasive alien species in Europe.

The DAISIE research project has produced invasive species accounts for three terrestrial fungi species, 18 terrestrial plant species, 16 terrestrial invertebrate species, 15 terrestrial vertebrate species, 16 species found in inland waters and 32 species from coastal waters. These species invade European natural and semi-natural habitats and already cause or have the potential to cause severe environmental, economic and/or health problems. The species were nominated to the list by experts working within the DAISIE research project. They are perhaps not the 100 most invasive alien species in Europe, but rather representatives of all main taxonomic groups and all environments and were selected so as to represent diverse impacts on ecology, socio-economic values and human and animal health. The species accounts were written by experts in the specific taxon and are based on the most up to date information available, both published and unpublished. The names of these species are given in bold throught the book. Each DAISIE species account includes information on the following aspects:

Description: First we give a short description of the species aimed at helping the reader to identify the targeted species. Further information focuses on the characteristics related to the species' potential to reproduce, establish and successfully invade new areas as well as dispersal mechanisms for the species.

Habitat: The account also includes the habitat type where the species is found in its native and introduced range. In order to make habitat types comparable for a wide range of taxa across diverse biomes we adopted the EUNIS habitats classification, a standard classification of European habitats according to Davies and Moss (2003). We used habitats described at the hierarchical level 1 which indicates 10 broad habitat types (e.g., C: inland surface waters, F: heathland, scrub and tundra habitats, etc.). Where these habitats were too heterogeneous with respect to the level of invasion, we also used habitats at the finer hierarchical level 2 which accounts for geographic and topographic differences. (e.g., F2: arctic, alpine and sub-alpine scrub; F3: temperate and Mediterraneo-montane scrub). Where information was 
available, we included specific habitat requirements that might improve our understanding of environmental factors limiting species spread.

Distribution: The area of distribution of the species in its native and invaded range is described. For some species there is very precise information on its global area of distribution, but for other species only references to a continent or region could be made. The distribution trend of the species in its European range is also described, but the quality of this information varies greatly. For many species expertise could only indicate if the species is currently increasing, decreasing or remaining stable.

Maps of the most up-to-date known distribution were based on the available information on the species distribution in Europe and in some adjacent regions such as the Mediterranean Sea. Maps are based on detailed surveys of regional sources of information. However, the missing occurrence of species from some parts of Europe, especially in south-eastern countries, does not always mean that these areas are not invaded, rather this can be the result of a lack of data. It is important to highlight that maps do not include assumed distribution. If enough precise information on species distribution was available then the CGRS grid (Common European Chorological Grid Reference System; size of the grid $50 \times 50 \mathrm{~km}$ ) was used. Everywhere else the distribution is shown by using geographic/political regions or by the combination of CGRS grids and regions. For each geographic region the species distribution was also classified as native or alien. Whenever it was relevant and data were reliable enough, the maps also indicate eradication or extinction records.

Introduction pathway: This information is essential for early detection and management. As well as mentioning if the species has been intentionally or unintentionally introduced, we include information on whether the primary route of introduction to and within Europe has taken place through commodities, if the species has been transported by a vector, or if it has been dispersed unaided or through a man-made corridor (Hulme et al. 2008).

Impacts: Since actions against biological invasions are often only supported where there is evidence of some type of ecological and socio-economic impact, and particularly when affecting human health, special emphasis has been given to the description of all known impacts that have been reported or could potentially occur (Binimelis et al. 2007). As an example, $71 \%$ of the species listed reduce species diversity or alter the invaded community and 19\% affect the viability of endangered species. Overall, the 100 invaders represent a broad spectrum of impacts to ecosystem services.

Management: This section is particularly dedicated to land and wildlife managers already concerned about the hazards of biological invasions. Experience regarding mechanical, chemical and biological control methods, either successful or unsuccessful are reported. Prevention strategies are also included. Unfortunately, for many species, especially in aquatic biomes, successful management options are unknown.

References: No references are included in this printed version of the DAISIE accounts. However, an extensive literature list for each species can be found at www.europe-aliens.org. 
Overall, the DAISIE species accounts offer information on the main ecological aspects and impacts of 100 of the most invasive alien species in Europe, and contribute to the initiatives on raising awareness on this phenomenon of global change. We hope that the DAISIE accounts will be of benefit to many people with interest and responsibilities for preventing and managing biological invasions in Europe and beyond.

\section{References}

Andreotti A, Baccetti N, Perfetti A, Besa M, Genovesi P, Guberti V (2001) Mammiferi ed uccelli esotici in Italia: analisi del fenomeno, impatto sulla biodiversità e linee guida gestionali. Quad Cons Natura, 2, Min. Ambiente, Ist Naz Fauna Selvatica

Binimelis R, Born W, Monterroso I, Rodríguez-Labajos B (2007) Socio-economic impacts and assessment of biological invasions. In: Nentwig W (ed) Biological invasions. Ecological Studies 193, Springer, Berlin. 331-347

Capdevila-Argüelles L, Zilletti B (2006) Top 20. Las 20 especies exóticas invasoras más dañinas presentes en España. Edition GEIB, León

CIESM The Mediterranean Science Commission (2007) Atlas of exotic species in the Mediterranean. www.ciesm.org/online/atlas/index.htm. Cited Dec 2007

Cronk QCB, Fuller JL (2001) Plant invaders: the threat to natural ecosystems. Island Press, Washington DC

Davies CE, Moss D (2003) EUNIS habitat classification, August 2003. European Topic Centre on Nature Protection and Biodiversity, Paris

EEA (2007) Halting the loss of biodiversity by 2010: proposal for a first set of indicators to monitor progress in Europe. European Environment Agency, Technical Report 11/2007

Genovesi P, Scalera R (2007) Towards a black list of invasive alien species entering Europe through trade, and proposed responses. Convention on the conservation of European wildlife and natural habitats. Standing Committee 27th Meeting, Strasbourg, 26-29 November 2007. T-PVS/Inf 9

Gollasch S, Minchin D, Rosenthal H, Voigt M (eds) (1999) Exotics across the ocean. Case histories on introduced species: their general biology, distribution, range expansion and impact. Logos, Berlin

Hulme PE, Bacher S, Kenis M, Klotz, S, Kühn I, Minchin D, Nentwig W, Olenin S, Panov V, Pergl J, Pyšek P, Roques A, Sol D, Solarz W, Vilà M (2008) Grasping at the routes of biological invasions: a framework for integrating pathways into policy. J Appl Ecol 45:403-414

Love S, Browne M, Boudjelas S, De Poorter M (2000) 100 of the World's Worst Invasive Species. A Selection from the Global Invasive Species Database. www.issg.org. Cited December 2007

Mlíkovský J, Stýblo P (eds) (2006) Nepůvodní druhy fauny a flóry České republiky. ČsOP, Praha

NOBANIS (2007) North European and Baltic Network on Invasive Alien Species. www.nobanis. org. Cited 18 September 2007

Pascal M, Lorvelec O, Vigne JD (2006) Invasions biologiques et extinctions. 11,000 ans d'histoire des vertébrés en France. Quae-Belin Editions, Paris

Shine C, Williams N, Gündling L (2000) A guide to designing legal and institutional frameworks on alien invasive species. IUCN, Gland

Scalera R (2001) Invasioni biologiche. Le introduzioni di vertebrati in Italia: un problema tra conservazione e globalizzazione. Collana Verde, 103. Corpo Forestale dello Stato. Ministero delle Politiche Agricole e Forestali, Roma

Weber E (2003) Invasive plant species of the world: a reference guide to environmental weeds. CABI, Cambridge

Weidema IR (ed) (2000) Introduced species in the Nordic countries. Nord Environ 13:1-24 